\title{
The Future IT Governance: Reshaping Future Public Management
}

\author{
Ayuning Budiati ${ }^{2}$ \\ Faculty of Social and Political Science, University of Sultan Ageng Tirtayasa \\ (ruditko@yahoo.com)
}

\begin{abstract}
There are many problems internationally in IT governance, namely spamming, hacking, and virus attacking. In Indonesia, currently, Australia hacked Indonesian president and many important persons. Therefore, there is a need to improve IT governance in Indonesia for more effective public management. The writer argues that there are three aspects in improving IT Governance for more effective public management in Indonesia in the future, namely: more control in virtual for people and physical for states, states have to practice two foreign policies and two domestic policies - one for the virtual world and one for the physical world, and more cost in privacy and security.

Keywords: IT governance, legislate on IT policies, privacy and security.
\end{abstract}

\section{Introduction}

The use of IT (Information Technology) is not a panacea in all problems of public management. IT Governance is managing IT implementation. In public management issue, then IT Governance is a way of managing IT as a tool in public service delivery. New Public Management has aims namely, financial transparency, linking performance indicators to outputs, and attributing costs to outputs (Chaston, I, 2011: 302). Regarding that aims, at present, Indonesia uses IT or e-government (electronic government-one of New Public Management issue) in delivering public services. The reason is e-government can improve efficiency, effectiveness, transparency and accountability in public service delivery. However, there are still many obstacles in improving more effective IT Governance in Indonesia, namely lack of privacy in IT governance implementation and lack of security management - such as, spamming, virus issue and hackers. These obstacles are regarding also as an ethical issue.

This paper is for analyzing IT Governance implementation for more effective public management - especially, in public service delivery. The writer argues that there are three aspects in improving IT Governance for more effective public management in the future, namely: more control in virtual for people and physical for states, states have to practice two foreign policies and two domestic policies - one for the virtual world and one for the physical world, and more cost in privacy and security(Schidt, E \& Cohen, J. 2013:255). This paper uses literature study.

\section{IT Governance: Reshaping The Future Public}

\section{Management}

IT Governance is how to manage the use of IT. Weill, P \& Ross, J.W state IT governance is the decision rights and accountability framework to encourage desirable behavior in using IT. IT governance can improve public management, for example in conducting e-government, e-administration, eprocurement in Indonesia.

Indonesia has conducted e-government since 2003 (President Instruction No. 13 Year 2003). In average Indonesian government and local governments are still in information stage. However, e-procurement in West Java had been conducted three years ago and had been won national best e-procurement. For example, there are better bidding and transparent processes. 
In improving public management internationally, there are three aspects that need to be improved (Schmidt, E \& Cohen, J, 2013:255), namely:

a. More control in information technology and physical for states

Control needs in virtual for people and physical for states. Meaning control needs in handling people's activities virtually. Control also needs in physical implementation in states' issue- such as control in building infrastructure for public service delivery. In the future there will be more connectivity and technological opportunity, the reason is because the virtual and physical civilizations will affect and shape each other. The world will be more egalitarian, more transparent and more interesting than we can even imagine (Schmidt, E \& Cohen, J, 2013:255).Therefore, more control is needed in IT and physical issue for states.

In Indonesia, we have regulation No 11 Year 2008 about ITE (Information Technology and Electronic Transaction) to regulate or controlling virtual activities and its relation with the state or egovernment. For example: citizen can use the internet to download tax form (land and building tax) and pay it by credit card. Meaning, government can control tax payment. However, not all Indonesian can access the internet, therefore not all tax revenue can be known immediately (only 67 million Indonesian can access the Internet-in year 2011).

b. Legislate much on IT: Policies on Virtual world and physical world

In the future, there will be more virtual relationship among citizens and among nations, therefore there is a need of policies on virtual world and physical world. States will have to practice two foreign policies and two domestic policies - one for the virtual world and one for the physical world (Schmidt, E \& Cohen, J, 2013: 255).

OECD in 1998 argues to conduct five actions to improve governance in public sector, namely:

1) Developing and regularly reviewing policies, procedures, practices, and institutions influencing ethical conduct in the public service.

2) Promoting government action to maintain high standards of conduct and counter corruption in the public sector.

3) Incorporating the ethical dimension into management frameworks to ensure that management practices are consistent with the values and principles of public services.

4) Combining judiciously ideal-based aspects of ethics management systems with rule-based ones.

5) Assessing the effects of public management reforms on public service ethical conduct.

(Chaston, I, 2011:303)

Based on those actions, to improve IT governance at public sector in policy issue then the government should develop policies-including policy in IT issue. Ethical issue also should be considered strategic to be improved. Hacking other people email or phones is not ethical action. Ethical issue should be provided by the government. Hacking is also against international law. Moreover, in IT point of view an encrypting as a firewall to protect our IT implementation.

c. More costs in privacy and security in IT

As many problems in privacy and security issues, therefore there is a need more focus in handling privacy and security in IT governance. As Bellamy and Taylor in Hughes, O.H (2003:197) state privacy and security are important aspect in the use of IT by the government (electronic government).Security is 
currently inadequate, hackers have been able to interfere relationships among countries.

In Indonesia, privacy and security issue is handling by regulation (UU No 11 Year 2008 about Information Technology and Electronic Transaction). Public Private Partnerships can be a solution to have better funding in handling privacy and security in IT. Indonesia is still needs more collaboration among the technology industry, the public sector and civil society enormously.

\section{Conclusions}

In the international new digital era, there is a need of improving some aspects in IT governance as an effort in improving public management; namely more control in virtual for people and physical for states, states have to practice two foreign policies and two domestic policies - one for the virtual world and one for the physical world, and more cost in privacy and security. Those aspects are strategically important in handling obstacles at current issue in public management implementation in governance, such as spamming other countries' data bases, hacking other countries leaders' emails and virus obstacle in IT Governance implementation.

\section{References}

(1) Chaston, I. (2011). Public Sector Management: Mission Impossible? New York: Palgrave Macmillan. (2) Hughes, O.E. (2003). Public Management \& Administration: An Introduction. New York: Palgrave Macmillan.

(3) Pikiran Rakyat. Desember 2012. Keamanan Sistem Informasi.

(4) Schmidt, E and Cohen, J. (2013). The New Digital Age: Reshaping The Future of People, Nations and Business. New York: Alfred A. Knopf.
(5) Weill, P \& Ross J.W. (2004).IT Governance: How Top Performers Manage IT Decision Rights for Superior Results. Boston: Harvard Business School Press. 